\title{
Media economics research: a history of the field
}

\author{
Alan B. Albarran
}

The overarching goal of this volume is to establish a research agenda for the field of media economics. To look forward, it is helpful to first consider the history of this area to understand its nuances and development as an area of study. "Study the past if you would define the future" is a quote commonly attributed to Confucius and is relevant to the task faced by the editor and contributors of this volume. While we may not be able to predict future trends for the field of media economics, we do hope to offer guidance and suggestions for new generations of PhD students and scholars interested in this rapidly changing field over a variety of topics.

\section{What is media economics?}

Media economics is a sub-field developed out of the larger area of general economics. Media economics involves the application and study of economic theories and concepts to the media industries (Albarran, 2017). In terms of theories, much of the development of the field has been influenced by theories based in microeconomics, such as the industrial organization model and the theory of the firm. Concepts drawn from mainstream economics include the firm, the industry and different types of markets (for example, monopoly, duopoly, oligopoly, monopolistic competition, perfect competition) all found across media economics research. There are also concepts developed to help explain specific aspects of media economics research such as the dual product market, media competition and multiplatform distribution.

Macroeconomic theories have also influenced scholars interested in media economics. Among these are studies related to aggregate economic activity such as gross domestic product (GDP) and gross national product (GNP) metrics, public policy actions in the form of laws and regulation, and labor and employment trends. Interest and inflation rates are important macroeconomic concepts.

A further strand of theories revolve around the area known as political economy, a critical approach with origins in Marxism, which looks at topics such as media hegemony and technological determinism. Political economy developed as an alternative view of media economics research. In this volume, our focus is on the mainstream areas of research drawn from microeconomic and macroeconomic 
perspectives, and not political economy. Readers interested in political economy of the media should consider works by scholars such as Garnham (1979), Mosco (1996), McChesney (2008) and Wasko et al. (2011) for a good introduction to the subject.

In the following section a brief history and development of economic thought is presented. This overview will help clarify the evolution of economics and its application to various sub-areas of study such as media economics.

\section{Economic thought and the study of economics}

Economics in various forms has existed since the beginning of mankind, in the sense that people have always engaged in barter and trade to acquire needed resources such as food, shelter, clothing or medicine. Market activity involving buyers and sellers were key aspects of early Greek society (circa 1000 BC) along with the development of city-states. Early Chinese coins date back to $760 \mathrm{BC}$. The Roman Empire at its apex conquered much of what is now Europe and introduced a common currency and levied taxes on subjects.

Over time, these early influences led to the formation of economic and political systems concerned with the allocation of basic resources, the notion of supply and demand, the needs and wants of markets and consumers, and the production and distribution of goods and services. Throughout much of world history, a nation's wealth was based on its ability to leverage its resources and land, especially trade between nations. Technology also became a driving force, as advances in technology enabled more efficient production and labor practices.

The 17th century is when economics came of age; a group of philosophers in France, known as the physiocrats, recognized that a nation's wealth at that time was determined by agriculture and land development, which made sense in an era when farming was the primary global occupation. The work of the physiocrats influenced other early economists such as Adam Smith, Jean-Baptiste Say, David Ricardo, John Stuart Mill and Thomas Malthus, just a few of the founders of what we know as the Classical School of economics.

The Classical School argued for a free market system that would be self-correcting (for example, Adam Smith's concept of "the invisible hand") to stimulate production and wealth for all. The Classical School helped better explicate key concepts such as markets, supply, demand and elasticity, but also drew critics who recognized many shortcomings. Hence, alternative theories and philosophies began to emerge over time.

Other schools of economic thought would develop in the decades to follow. Marginalists were primarily interested in the concept of marginal utility to explain why prices differed among goods and services. Works by Carl Menger, Léon 
Walras and William Stanley Jevons were influential in the rise of marginalist thinking.

Neoclassical (new economics) thinkers introduced several important ideas-people have rationale preferences associated with value; that individuals maximize utility; firms seek to maximize value; and both individuals and firms have adequate information to make economic decisions. Some of the important early contributors to neoclassical economics included Alfred Marshall, Joan Robinson, Edward Chamberlin and Oliver Williamson.

The Austrian school of economics integrated ideas from both neoclassical and marginalists in studying economic behavior of individuals. Important names associated with the Austrian School are Carl Menger, Ludwig von Mises, Friedrich Hayek and Israel Kirzner. In Germany, the History School (of economics) believed history was the best source to understand economic matters and it produced several important scholars, among them Gustav von Schmoller, Max Weber and Joseph Schumpeter.

Keynesian economics, a school devoted to macroeconomics based on the works of its founder John Maynard Keynes, gained importance beginning in the 1930s, and illustrated the important role that labor and government policy plays in an economic system. In the United States, the Chicago School has continued advancing new approaches to macroeconomics since its founding in the 1950 . Some of the important scholars identified with the Chicago School include Ronald Coase, Gary Becker, George Sigler and Milton Friedman.

More modern manifestations of economic thought include the rise of monetarists like Friedman (1950s) and the notion of "rational expectations" in markets, first proposed by John Muth in 1961. Supply-side economics, whose advocates date back to Adam Smith and Alexander Hamilton, was reintroduced by the Reagan administration during the 1980 os in the United States as a means toward economic growth, manifested by a combination of tax cuts and reduced government spending. William Baumol is another prolific modern scholar in the area of macroeconomic thought.

In the 21st century, a global recession (2007-9) forced the dominant central banks (Federal Reserve, Bank of England, Bank of Japan, European Union Central Bank) to coordinate economic policy to prevent a global depression. The central banks sliced interest rates to record lows and further stimulated their respective economies by purchasing government bonds (also known as quantitative easing, or simply QE). Combined, these efforts flooded the markets with cash that could be borrowed cheaply and hopefully spur economic growth. The global recession illustrated a new twist in macroeconomic policy by showing how the global financial markets are interconnected and interdependent on one another.

The history of economic thought and its various schools continue to influence economic activity around the globe, and impact every area of society, business and 
industry. Hence, the contemporary study of economics is now broken into numerous sub-fields, with each area having its own unique approach to understanding economic activity. For example, one can find a great deal of economic-related research on areas such as labor, transportation, retail and consumer spending, health care, real estate and travel, to name just a few. We can add to that list the entire realm of communications and communication services, which encompasses media economics.

Each of these sub-areas of economic activity may be examined by different audiences for different purposes. Many of these economic sub-fields are found at colleges and universities, represented by different courses or even separate departments with specific tracks of study. Another audience for economic activity is government, non-government and non-profit institutions, represented by various bureaus, agencies or departments. Still another audience of interest is the business investment community, which consists of everything from individual corporations to investment bankers, hedge fund managers and research firms/ analysts.

Economics is therefore a critical and broadly identified area of inquiry. By drilling down into specific industries one can learn about the intricacies and any unique characteristics. Given this overview, we can now turn our attention to the media industries and the rise of media economics research.

\section{The media industries and media economics research}

The media industries continue to be part of an ongoing evolution reflected in media economics research. From a historical perspective, print products in the form of newspapers, books and magazines represented the earliest forms of "media" thanks to the innovation of printing and mass distribution, which took shape in the late 19th century. Wireless communication was the forerunner for radio broadcasting in the early 1900s, followed by television in the 1940s. The introduction of cable and satellite technology in the 1970s created multiple channels of entertainment and information leading to new areas of study. The digital revolution has further expanded our understanding of media with the rapid development of the internet, which exploded after the introduction of the commonly adopted hypertext markup language (HTML) in the early 1990s. Another technological wave driven by smartphones began in 2007 with the debut of the iPhone. The rise of social media and new communication technologies is challenging assumptions regarding how we should define the media industries in 21st-century society.

Media economics research mirrored each of these waves of media industry growth, although it would be decades before initial research would appear. For example, the first economic studies on the newspaper industry emerged in the 1950s (see Ray, 1951, 1952). Early studies related to the economics of broadcasting and broadcast regulation followed in the same decade (see Coase, 1950). 
Early research tended to be descriptive in nature and centered on a single industry. In fairness to the initial scholars interested in what we call media economics, there were few theories to offer guidance, little in the way of methodologies, and limitations on available public data on either the firm or the industry.

These challenges forced researchers to develop ideas to guide study and inquiry. What exactly did researchers hope to understand about the economic aspects of the media? There were no journals devoted to media economics (the first journal, The Journal of Media Economics, began publishing in 1988), and few books existed. Compared to the larger umbrella of mass communication studies, there were only a handful of scholars even interested in business and economic research, and no conferences devoted to media economics research emerged until 1994.

What follows is a concise history of media economics research broken down into four distinct eras of development. Of course, any such timeline is arbitrary as there is no agreement on such a subject. The eras and dates presented represent the author's interpretation of the field and its evolution. However, at the least it should serve a heuristic function as a starting point for discussion of understanding the history of media economics research.

\section{A condensed history of media economics research}

\section{The first era of media economics research (1950-75)}

How then to describe this first period of media economics research? While there is no known consensus on any sort of timeline, the research published between 1950 and 1975 tended to be disparate in nature and addressing topics of interest to the researcher(s) conducting the study. Most of the research originated in either North America (the United States and Canada) or Europe (primarily in the UK, France and Scandinavian countries). Most research covered a single period as opposed to any sort of longitudinal panel or time-series type of study. Microeconomic studies dominated this early research period.

Studies related to ownership were also common to this first period of study, as well as examinations of how regulatory policy affected the economics of the media. Studies on advertising and consumer spending on the media illustrated the unique dual-product market identified with media economics research.

While most of the research was published in scholarly journals, a few books appeared. The first published book was probably Coase's examination of the British broadcasting monopoly (1950). Nieto authored books on the Spanish press (1968, 1973). Schiller (1969) wrote one of the early books on political economy of the media. Owen et al. (1974) examined issues related to the economics of the television industry. Owen (1975) also authored an influential book examining economics and freedom of expression. These books contributed to the foundational literature published in this first wave of media economics research. 


\section{The second era of media economics research (1976-95)}

The period from 1976 to 1995 brought many changes to the media industries and to media economics research as the research grew more sophisticated as data and methods of analysis improved. Cable and satellite television began disrupting the broadcast television industry, introducing a different business model (monthly subscriptions) with different tiers of service. The explosion of video channels created fragmentation among audiences and expanded interest in audience research and consumer choice. Newspaper circulation had by the mid-1970s peaked in many nations, portending a long secular decline for the print medium. Home video finally had its debut after years of courtroom battles to delay its introduction to consumers, with the introduction of the Betamax and the ubiquitous VHS machines.

Researchers relished the numerous areas available for study aside from the "traditional" media industries of print, television and film that dominated the first period of media economics research. The growth of multichannel television services (cable, satellite and later telco-based systems), premium television services (such as HBO, Showtime), pay-per-view options (PPV), and direct-to-home video (designed to sell/rent physical media such as tapes and cassettes) in turn fueled a greater need for video content to meet consumer demand, the majority of it in the form of scripted and non-scripted TV programming and movies.

Because of the increasing costs of content production and licensing for distribution, most of the media industries began to consolidate, as larger companies bought or merged with other companies. There were several waves of mergers and acquisitions during this era, resulting in increasing concentration of the media industries. In many nations, relaxed regulatory policies and liberalization of the media industries became commonplace, leading to still more consolidation. Media companies were able to engage in economies of scale (lowering costs within their holdings) and economies of scope (lowering cost structures across industries) because of increasing commodification.

Increasing consolidation led scholars to examine media concentration using a variety of methods to attempt to quantify the level of concentration found within and across the media industries (see Albarran \& Dimmick, 1996; Noam, 2016). Among the tools employed were concentration ratios calculating the share of the market of the top four and top eight firms; the Lorenz curve, which provided a graphical representation of concentration in a market, and the Hirschman-Herfindahl Index (HHI), used by the United States Department of Justice in antitrust cases. Other scholars introduced various weighted measures to refine efforts to gauge concentration. But one pitfall of these efforts was that they offered a picture at a specific point in time of the level of concentration in a market. The next merger or acquisition would change the data, requiring concentration to be studied on a continuing basis. In most countries in the developed world, media concentration was found to be very high, yet few actions were taken by policymakers to stem media consolidation. 
Other topic areas emerged as well, among them investigations further examining the principle of relative constancy, first explicated by McCombs (1972). Niche theory, drawn from biology, was applied to the media industries using several formulas created by Dimmick and Rothenbuhler (1984) to measure the concepts of breadth, overlap and superiority. Policy and regulation also became frequent topics of investigation, along with studies examining financial performance of media companies, valuation of media properties, and diversification of media products and portfolios.

New scholars began to appear from several Asian countries-notably Japan, South Korea, Taiwan and Australia. Programs focused on media management and economics took root in many European nations as well as the United States, with new $\mathrm{PhD}$ and MA programs established during this second wave.

Scholarship began to grow with the publication of several books devoted to media economics or media economics issues. The first textbook on media economics was authored in France by Toussaint Desmoulins (1978). Other important texts published during this second wave were authored/edited by Compaine et al. (1979); McFadyen et al. (1980); Picard (1989); Owen and Wildman (1992); and Alexander et al. (1998).

One of the most important milestones during this second era was the establishment of the Journal of Media Economics (JME), edited by Robert Picard, which began publishing in 1988. JME became a home for those interested in media economics, and it quickly grew in stature and interest. The first international conference devoted to media economics took place in 1994, which grew to become the World Media Management and Economics Conference, a biannual conference uniting scholars from around the globe.

\section{The third era of media economics research (1996-2010)}

The third era of media economics research mirrored many aspects of the second, in that massive changes occurred across the media industries as interest and development of the field of media economics grew larger. The media industries were impacted by five major developments: (1) the transition to digital media from analog-based media; (2) the rapid growth of the internet and digital platforms; (3) the debut of the smartphone (beginning with the iPhone) in 2007; (4) the rise of social media; and (5) the introduction of streaming media.

It should be noted, without exaggeration, that any one of these developments would have changed the media ecosystem. Taken as a group, this era introduced incredible structural and social changes regarding the relationship of media to society as convergence impacted the media industries. Some day this era may be looked upon in the same way that history looks at the industrial revolution as a series of events that transformed the world. In addition to these five forces, growing globalization of goods and services, and a period where many governments deregulated media policies, led to further changes across the media industries. 
Technology-driven companies captured the attention of investors during this era, leading to labeling the group as FANG, representing Facebook, Amazon, Netflix and Google. Soon Apple was added as a second company representing the letter A. These companies have tremendous market power, driven by their dominant position in various markets: Facebook (social networking), Amazon (e-commerce), Apple (mobile devices), Netflix (subscription video) and Google (search). Together, these companies control huge amounts of data on consumers and their preferences for spending time and money, spawning an entire new industry known as "big data," a topic discussed in several chapters in this volume.

The continuing technological revolution and the rise of tech-driven conglomerates generated more interest in media economics research from scholars around the globe. More universities began offering courses and programs around media economics, expanding to every region of the world. Numerous books devoted to media economics were published around the globe, examining both domestic and international markets from different perspectives. The first handbook (Albarran et al., 2006) for the field was published during this era, to be followed by other handbooks. These compilations helped summarize the development of media economics and media management and establish new research agendas for scholars to consider. New journals related to media economics emerged, most notably the International Journal on Media Management founded in St Gallen, Switzerland by Beat Schmid in 1999, and the Journal of Media Business Studies founded in Jönköping, Sweden by Robert Picard in 2004.

Many research questions emerged for scholars to tackle, and among the most important was understanding how these new technological developments impacted the traditional media industries of printing and broadcasting. The proliferation of digital platforms provided more choice and greater control over consumption for consumers. The result of the expansion of platforms was an even greater fragmentation of audiences, virtually ending the notion of "mass" media. As eyes and ears shifted to digital media, advertisers and marketers quickly followed suit, putting pressure on the traditional media industries that relied on advertising as their main source of economic support. Interest in econometric modeling and analysis also represented another area of development during this era.

\section{Contemporary media economics research (2011-present)}

The fourth and current era of media economics research continues to be heavily influenced by technology and the many changes impacting the media marketplace, much more broadly defined than at any time in history (Albarran, 2017). For consumers, probably the biggest change is the clear preference for mobile devices (phones, tablets) to access media content, made possible by the expansion of broadband networks and better and faster mobile communication standards ( $3 \mathrm{G}$ to $4 \mathrm{G}$ to the emerging $5 \mathrm{G}$ ). Mobile phones became ubiquitous; everyone had at least one and the majority were smartphones, either using the Android (Google) or iOS (Apple) operating systems. 
Consumers use mobile devices for everything: accessing news and entertainment; searching for information via the internet; social media; for driving directions through GPS mapping; for texting and sharing photos; for shopping and e-commerce; for weather; email; and, of course, making telephone calls-to name the primary functions. Given the time being spent on mobile phones, new forms of devices began to offer larger screens for easier access for viewing and reading. Large-screen smartphones are also called "phablets" because of their hybrid look, resembling both a small tablet as well as a phone.

The mobile revolution spawned numerous research studies on everything from the key industry providers (case studies, economic analysis) to regulatory issues to consumer uses and adoption patterns to understanding the various motives and gratifications driving use. Many of these studies dealt with economic concepts such as allocation of time and money spent on mobile phone use. In 2014, the Apple watch appeared with much fanfare, adding a wearable device that offered many capabilities for users.

Social media platforms also drove the use of mobile phones as users could instantly share updates on daily activities. Users also shared images and short video clips with others, some newsworthy, others for entertainment. Facebook was the first social media platform to offer "live" capabilities, allowing anyone to "broadcast" anything with no type of approved standards. Twitter also followed this practice, as did other platforms. Initially, this led to abuse of the platform, as some people showcased criminal activities, even capturing murders and suicides. Social media became a controversial area for scholarly investigation, with multiple avenues of inquiry possible (Albarran, 2013).

Still other new technologies join an already crowded marketplace. Among the latest innovations are virtual reality (VR) and augmented reality (AR), both adopted first by the gaming industry to expand interest and make engagement with users even stronger as gaming became more active and lifelike. Artificial intelligence (AI) first brought many applications to the telecommunications area with use in providing customer service menus and the means to route phone calls. Amazon introduced Alexa in 2014, a virtual assistant designed for the home that was quickly followed by other competitors such as Google and Apple.

The internet of things (IoT) is a term used to represent the use of smart devices that will eventually make their way into homes as consumers upgrade everything from appliances to ventilation, security and lighting systems. The result, for those adopting these types of technologies, will be billions of new devices connected to the household network that is further connected to the global internet.

These new technologies offer economic potential, but there are numerous privacy and security issues to address. The data generated by these technologies, as well as by the FANG companies, lie at the center of these concerns. As users, most of us have no idea what happens to our data once it is voluntarily submitted to an 
application or technology, until we learn we have been hacked or are the victim of some type of identity theft. Further, ethical issues come into play as well regarding media companies and technology, a topic addressed later in this volume by María Elena Gutiérrez-Rentería.

This heavily-driven technology era will drive much of the interest of researchers in this current era of media economics research. There are many avenues to explore for scholars. For example, how do these technologies affect our understanding of markets and industries? How will these new innovations further impact consumers in terms of their attention and spending habits? How will business models evolve? What new theories and methodologies are needed to conduct research in this growing technological environment?

Clearly there are many questions deserving scientific investigation and inquiry. But to return to the purpose of this chapter, there are also questions that remain regarding the history and development of the field of media economics research. What follows is a suggested research outline for scholars to consider in this area.

\section{Research agenda}

Given this cursory introduction, we know when the field of media economics began. What we don't know is why a group of scholars, none of whom were trained specifically in something called media economics, began to study this area. No doubt interest in the media as a business drove interest, as well as a curiosity as to how media industries functioned and were different from other areas of inquiry. What is it about media economics that spurred interest in researchers?

- We need to begin by seeking to understand the philosophical basis for the field of media economics. Specifically, what were the epistemological and ontological orientations that inspired scholars to consider studying what would become media economics? Understanding these origins would help establish the basis for further development. Such studies would likely be historical in nature and require the use of in-depth interviews with key scholars as well as a review of their papers and research notes (if available for content analysis).

- We lack any type of biographies of the early scholars in media economics. The field has lost many scholars who influenced the study of media economics. A few of the most productive deceased scholars include Barry Litman, Harvey Levin, John Dimmick, Benjamin Bates, Mary Alice Shaver (United States); Alfonso Nieto (Spain); Karl Erik Gustafson (Sweden); Axel Zerdick (Germany); and Dallas Smythe (Canada) to name just a few. An historical profile of the key scholars in media economics is needed.

- The field also lacks comprehensive histories of many media companies, many of which were formed after years of mergers and acquisitions (for example Comcast, AT\&T, News Corp.). These company histories would be excellent 
topics for dissertations, or for historical-based studies. A related project would be the creation of a database of media companies, which could be updated as needed.

- Histories of individual media industries are also needed, to show how markets and business models, as well as products and services, have evolved over time. Think about the evolution of radio-emerging first as an AM medium only, then the addition of FM, to satellite, to digital radio and podcasting. Some physical and online encyclopedias exist that detail some industries, but both areas suffer from consistent review and updating.

- As a field, media economics has had little in the way of theory development as many theories were applied from economics and other fields. Yet, why and how scholars selected theories from other fields for use in their research is not well known. Such insight would be helpful to new PhDs and junior scholars. Similar insights would also be gained from a review of key methodologies used by researchers over time.

- Over the years of existence, media economics researchers have generated a lot of data, but sadly most of this data is not publicly shared or available for analysis. This is one reason why there are few studies like meta-analysis, longitudinal studies and time series investigations, as well as any secondary analysis of data found in the literature. Researchers should consider sharing their data sets publicly to encourage these types of studies.

These are just a few ideas to get started on a research agenda that would address the historical developments of the field of media economics. The time to begin these studies is now. Such an effort is herculean in nature but would also provide a wealth of information for new PhDs, junior scholars, and those considering graduate work in the area. Only by studying the past can we preserve the future of the field.

\section{Conclusion}

As a field of study, media economics will soon enter eight decades of existence. There is a strong body of literature to support future research, and there is more interest in the field than ever before-evidenced by books, academic journals, international and domestic conferences, and graduate programs devoted to media economics or offering courses in the area. Yet, much of the actual historical development-in terms of what initially motivated scholars, the reasons they selected the theories and methods used in research, and analyses of important companies and industries-is not well known. The opportunity to develop this knowledge base is a tremendous challenge for the field.

Ideally, some researchers will accept this call to action, and help to fill in the gaps from a historical standpoint. Such efforts would define the legacy of the founding scholars who came first, as well as establish an even firmer foundation for the work that lies ahead. 


\section{References}

Albarran, A. B. (ed.) (2013). The Social Media Industries. New York: Routledge.

Albarran, A. B. (2017). The Media Economy, 2nd edn. New York: Routledge.

Albarran, A. B., S. M. Chan-Olmsted \& M. O. Wirth (2006). Handbook of Media Management and Economics. Mahwah, NJ: Lawrence Erlbaum.

Albarran, A. B. \& J. Dimmick (1996). Concentration and economics of multiformity in the communication industries. Journal of Media Economics, 9(4), 41-50.

Alexander, A., J. Owers \& R. Carveth (1998). Media Economics: Theory and Practice. Mahwah, NJ: Lawrence Erlbaum.

Coase, R. (1950). The British Broadcasting Corporation, a Study in Monopoly. London School of Economics: Longmans.

Compaine, B. M., C. H. Sterling, T. Guback \& J. K. Noble (1979). Who Owns the Media? Concentration of Ownership in the Mass Communications Industry. White Plains, NY: Knowledge Industry Publications.

Dimmick, J. \& E. Rothenbuhler (1984). The theory of the niche: quantifying competition among media industries. Journal of Communication, 34(1), 103-19.

Garnham, N. (1979). Contribution to a political economy of mass-communication. Media, Culture \& Society, 1(2), 123-46.

McChesney, R. W. (2008). The Political Economy of Media: Enduring Issues, Emerging Dilemmas. New York: NYU Press.

McCombs, M. E. (1972). Mass Media in the Marketplace. Journalism and Communication Monographs, 24, Lexington, KY: Association for Education in Journalism.

McFadyen, S., C. Hoskins \& D. Gillen (1980). Canadian Broadcasting: Market Structure and Economic Performance. Montreal: Institute for Research on Public Policy.

Mosco, V. (1996). The Political Economy of Communication: Rethinking and Renewal (Vol. 13). Thousand Oaks, CA: Sage.

Nieto, A. (1968). El concepto de empresa periodística. Pamplona: EUNSA.

Nieto, A. (1973). La empresa periodística en España. Pamplona: EUNSA.

Noam, E. M. (ed.) (2016). Who Owns the World's Media? Media Concentration and Ownership Around the World. New York: Oxford University Press.

Owen, B. (1975). Economics and Freedom of Expression: Media Structure and the First Amendment. Cambridge, MA: Ballinger.

Owen, B. M., J. Beebe \& W. Manning (1974). Television Economics. New York: Ballinger.

Owen, B. M. \& S. S. Wildman (1992). Video Economics. Boston: Harvard University Press.

Picard. R. G. (1989). Media Economics. Thousand Oaks, CA: Sage.

Ray, R. H. (1951). Competition in the newspaper industry. Journal of Marketing, 15(4), 444-56.

Ray, R. H. (1952). Economic forces as factors in daily newspaper concentration. Journalism Bulletin, 29(1), 31-42.

Schiller, H. (1969). Mass Communication and American Empire. New York: Augustus M. Kelley.

Toussaint Desmoulins, N. (1978). L'economie de medias. Paris: Presses Universitaires de France.

Wasko, J., G. Murdock \& H. Sousa (eds) (2011). The Handbook of Political Economy of Communications. New York: John Wiley \& Sons. 